Portland State University

PDXScholar

\title{
Work in Progress: a Process Book of the Re- Branding of the Beaverton Farmers Market
}

\author{
Lauren Hurrle \\ Portland State University
}

Follow this and additional works at: https://pdxscholar.library.pdx.edu/honorstheses

\section{Let us know how access to this document benefits you.}

\section{Recommended Citation}

Hurrle, Lauren, "Work in Progress: a Process Book of the Re-Branding of the Beaverton Farmers Market" (2017). University Honors Theses. Paper 461.

https://doi.org/10.15760/honors.458

This Thesis is brought to you for free and open access. It has been accepted for inclusion in University Honors Theses by an authorized administrator of PDXScholar. Please contact us if we can make this document more accessible: pdxscholar@pdx.edu. 
Work in Progress: A Process Book of the Re-Branding of the Beaverton Farmers Market

by

Lauren Hurrle

An undergraduate honors thesis submitted in partial fulfillment of the requirements for the degree of

Bachelor of Arts

in

University Honors

and

Graphic Design

Thesis Adviser

Elisabeth Charman

Portland State University 


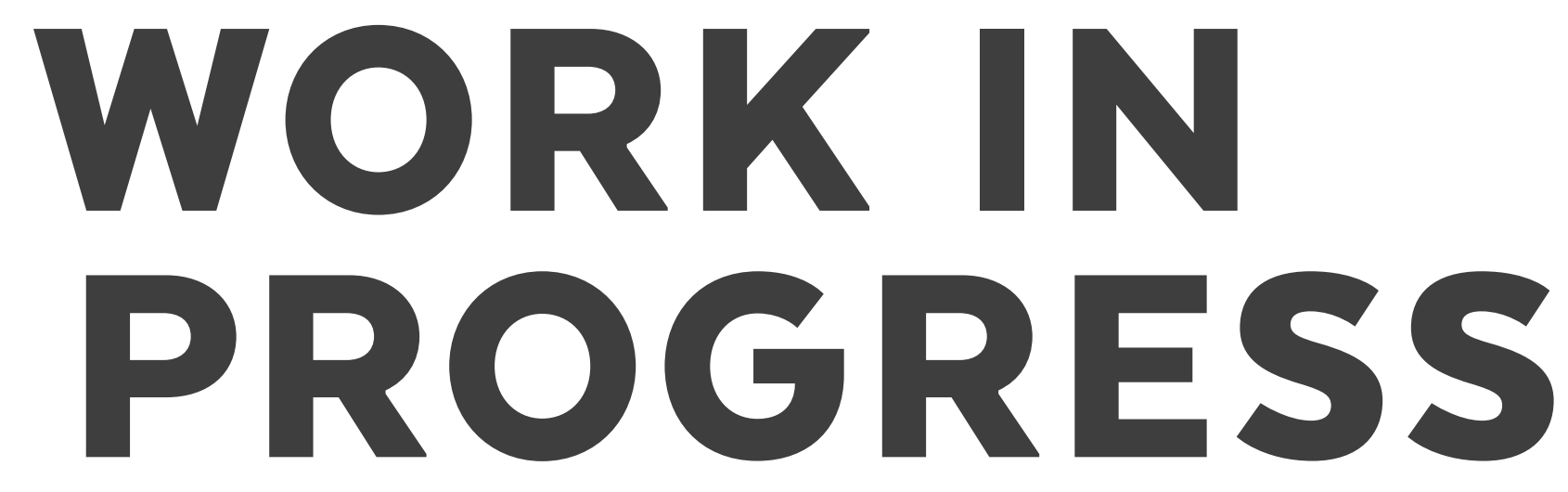

\section{A PROCESS BOOK OF THE RE-BRANDING OF THE BEAVERTON FARMERS MARKET}

\section{LAUREN HURRLE}

PORTLAND STATE UNIVERSITY 
WORK IN PROGRESS

LAUREN HURRLE 
BACKGROUND

As part of my junior-level branding class, I decided to re-brand the Beaverton Farmers Market, a place I grew up visiting. This was an

approximately four-week process in which I explored numerous routes

to best represent both the market and its location. I concluded the term

with many deliverables, an advertising campaign, and a "finished" brand

identity. However, I Itill feel as though I could spend countless hours more on the project.

Regardess of the cur ant state of complet on of he new branding

identity, it is irrelevant to the subject of this book. I highlight the design decisions I made along the way, as well as what I learned throughout, rather than focus on the current final product.

All New Seasons Market branding, photography, materials, and text copyright their 
4 CREATION (23)

5 CONCLUSION (35) 
1

IDENTIFYING

The Beaverton Farmers Market currently has all the necessities of a modern brand: a logo, a website, and social media. At the same time, the brand identity feels lacking. There is a noticeable lack of cohesion across print, the website, and the various social media outlets. So, what exactly is wrong?

THE MARKET AND ITS NEEDS

The word drop shadow, and the webste version of the mark fully omits the outline. There are two thick horizontallnes dividing "Beaverton" from "Farmers Market." Although he fill mank features a vector outhine of a shovel, pitchfork, and rake, the brand's aesthetic feels outdated. Current online presence for the market also clashes with the hard, computer-generated logo. The advertisements use paper textures, hand-drawn illustrations, a script typeface, and occasionally serif body copy. These are some of the many reasons I believe that the Beaverton Farmers Market needed a brand redesign. 
$\stackrel{2}{\text { RESEARCH }}$

PLANNING

Ultimately, the goal of the brand redesign of the Beaverton Farmers Market was to produce a modern, functional mark and cohesive advertising and web presence. More specifically, the mark had to be versatile with all the various applications: website, social media, business cards, print advertising, and even products. The advertising and web presence would need supportive imagery and typefaces.

PLANNING

CREATIVE BRIEF

BUSINESS COMPARISONS

eet these goals, brief, analyzing the trends of current farmers' market branding to avoid cliché designs, and comparing the Beaverton Farmers Market to its direct and indirect competitors. 
CREATIVE BRIEF

While a creative brief is often created through a series of interactions with the client, including interviews, meetings, and even informal discussions, the brief for the Beaverton Farmers Market was created solely through first-hand experience and studying the market's online presence. Athough this means that the information may not be as accurate because I was nnable to discuss the brand ident ty with the developing a strategy for the redesign of the brand.
History: The Beaverton Farmers Market is in Beaverton, Oregon, and they brary every Saturday from February through November Occasionally, local musicians and bands play. They sell a variety of fruit, vegetables, pastries, and other art isan goods. Like many farmers' markets, they specialize in local products.

Target audience: The Beaverton Farmers Market appeals to local families, as well as Spanish speakers in the community

Trends and observations: Next to the Portland Farmers Market, the nand metro rea, boasting 15,000-20,000 visitors on any given Saturday. While it Iready has some existing branding, the Portland Farmers Market has a better-established identity, as well as a clear, focused, and responsive website. Many of the other local cities do not have an established identity, so the Beaverton Farmers Market remains in a gray area between smaller markets and the Portland Farmers Market
Client observations: The Beaverton Farmers Market has not changed is difficult to navigate, and it contains outdated information and dead nnks. There seems to be little advertising about the market. They do not dvertise any products for purchase, such as shirts or tote bags. With refined identity, and more advertising and products for purchase, the Beaverton Farmers Market could thrive even more.

Market materials: The Beaverton Farmers Market only appears to be advertising through social media.

and strategy: The Beaver Wrket it is in the something unique compared to the Portland Farmers . more family friendy, cheaper and easier to park in, and more accesst to locals on the west side than downtown Portland. It is right next to the park, fountain, and library, which is perfect for a family outing afte visiting the market
Brand attributes: Family friendly, approachable, fun, engaging, colorful. easily identifiable

Tagline: The tagline for the Beaverton Farmers Market will focus on connecting families with the community and the marke.

Defverables. Logo, busmess cand, posters, postcards, tote bags, shirts, sandwich boards, website, social media

Goals: The Beaverton Fammers Market needs to establish a more community-oriented identity. The current identity feels too cold and reserved in contrast to the actual feel of the market. Highlighting the location of the market can help draw more families in. Creating wetdesigned tote bags, shirts, and other products for phrchase will not on ncrease revenue for the narket, but it will also act as an advertisement Beyond sellable goods, advertising through postcards and a refined social media presence will continuously attract new patrons. 


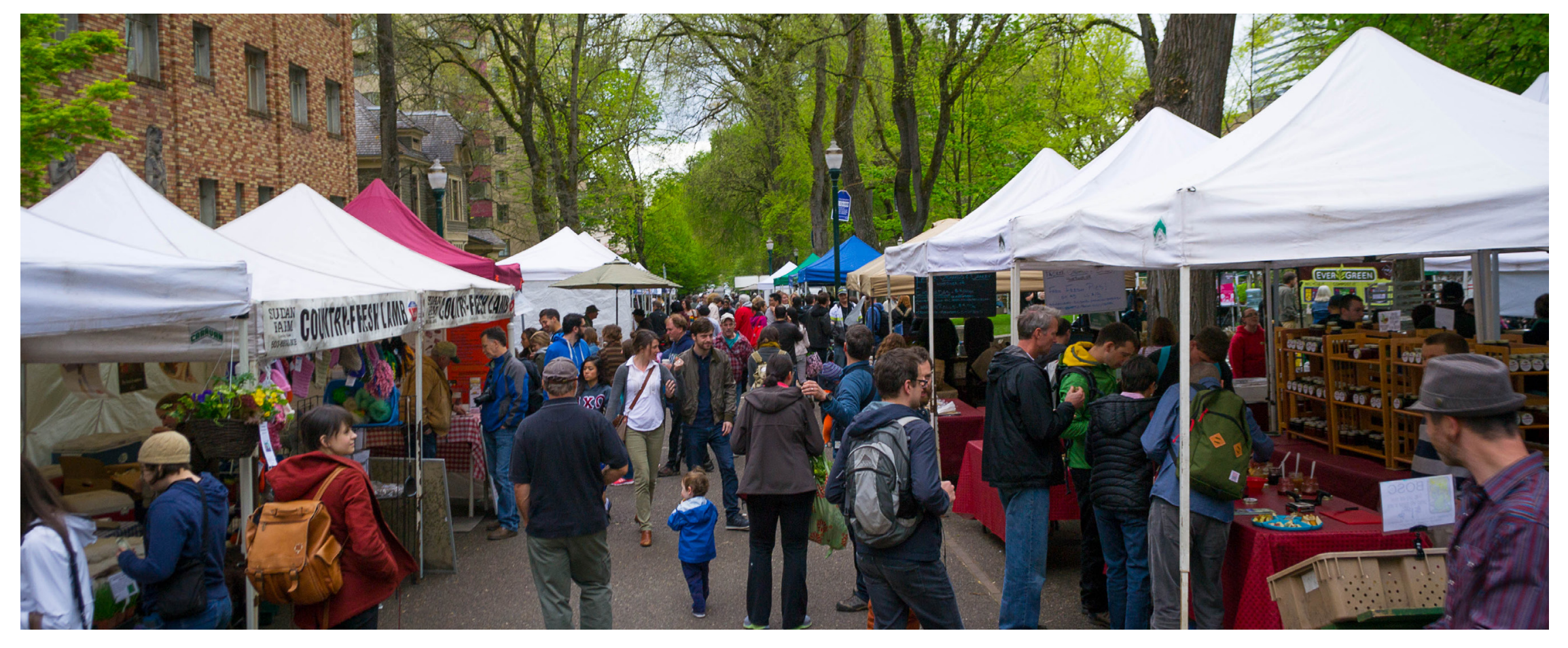

BUSINESS COMPARISONS

Researching existing competitors in the market serves as a great way to

see what your brand must compete with This includes everything from

its logo, to its color scheme, and even location These are rather quick

nformal observations but it can help you recognize the shortcomings in

your brand and analyze the significance of certain factors especially in

social media and web presence.

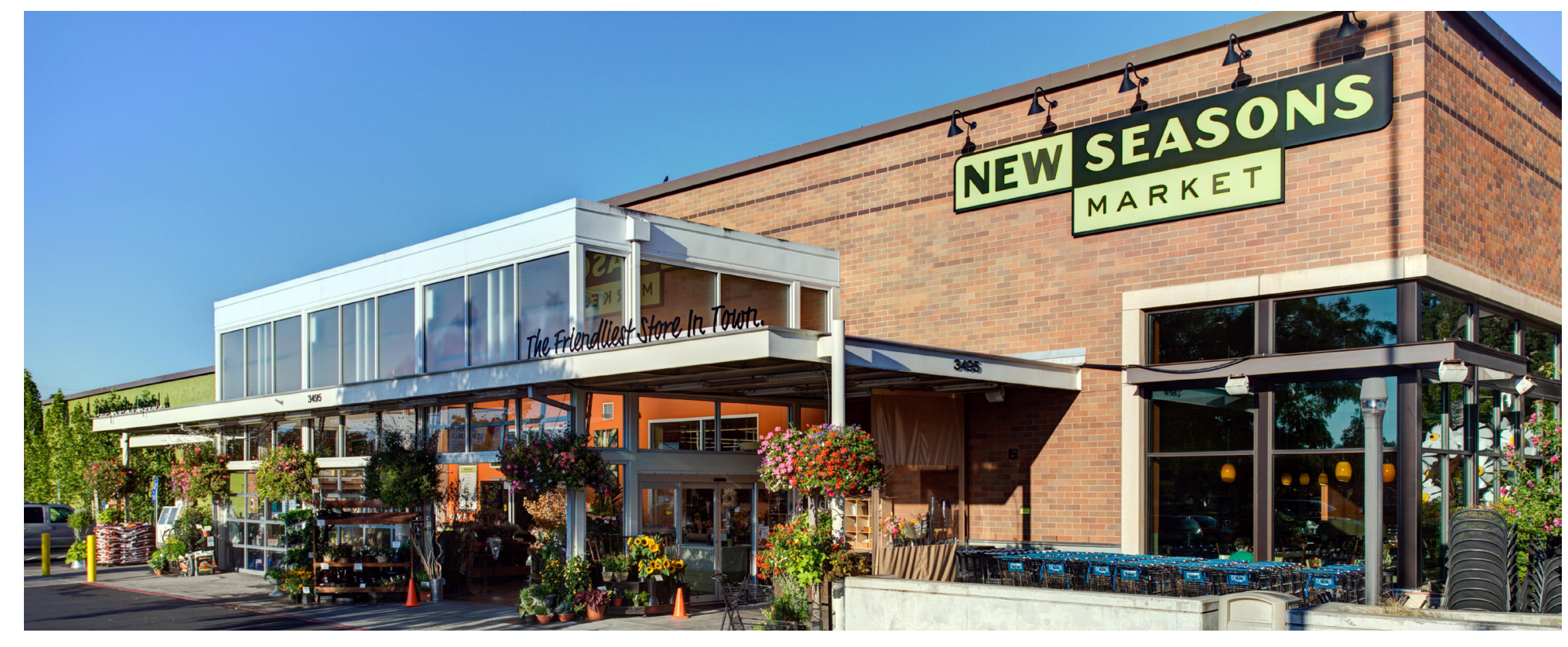

PORTLAND FARMERS MARKET

The Portland Farmers Market is a local, direct comparison to the

NEW SEASONS MARKET highlight community gatherings.

Audence. locals and fammines

Wordme hendy sans sent,

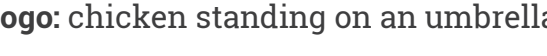

color

Toge style vector histran, texure, photography

Location. the heart or the pank blocks, downtown Po

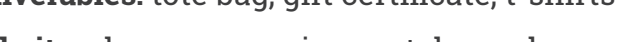

wer

organic products from many local sources.

The

Worme

rounded-edge boxes

handwritten elements

ific Northwest and California

作 


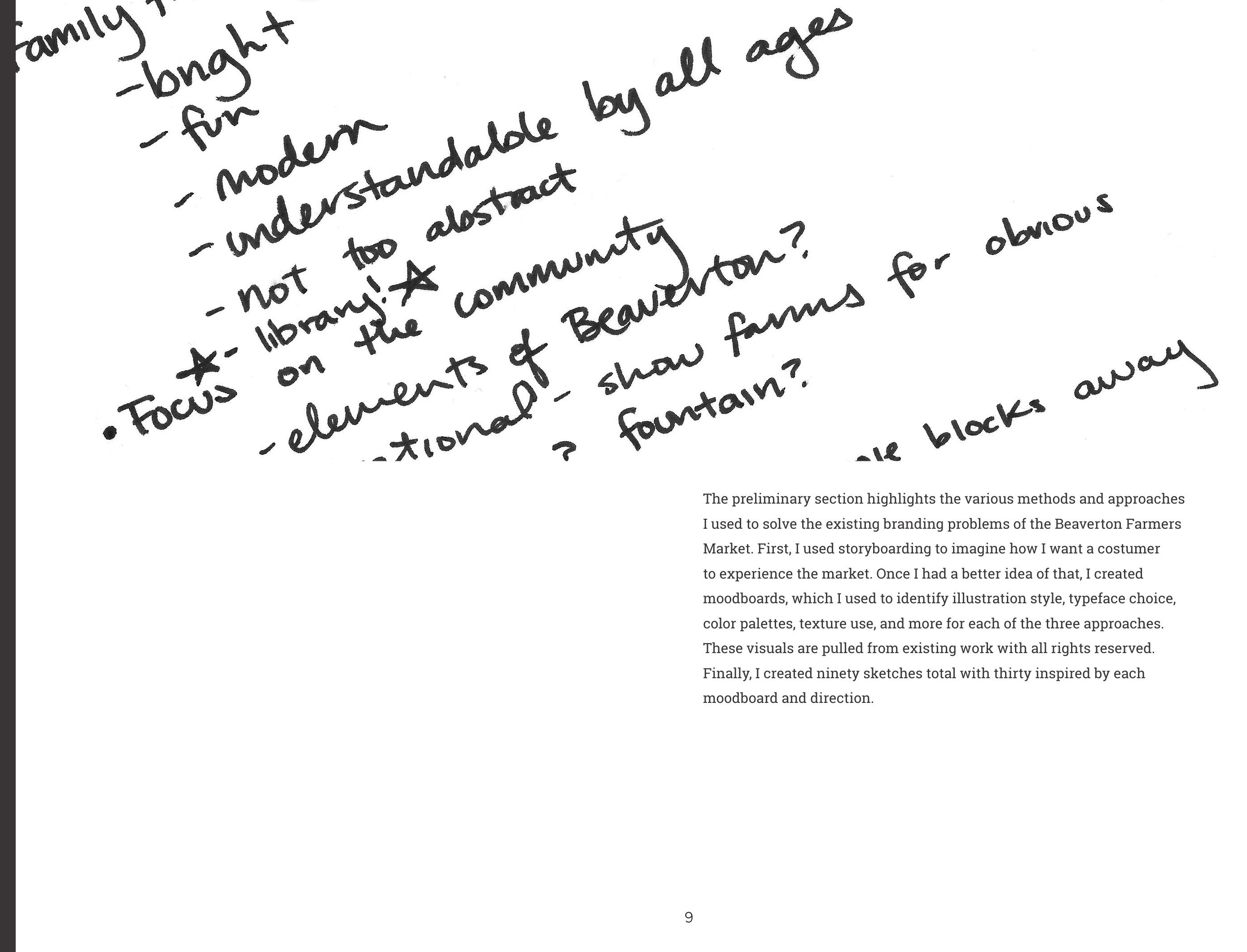




\section{STORYBOARDS}

These storyboards were quick sketches of how a potential consumer postcard she received in the mall from the Beaverton Frmers Market. Hypothetically, she had not gone before. Once she and 政 library. The Beaverton Farmers Market has prepared food, plus sweets and other snacks, so combined with a visit to the library, it made for a nice, inexpensive outing with the family.
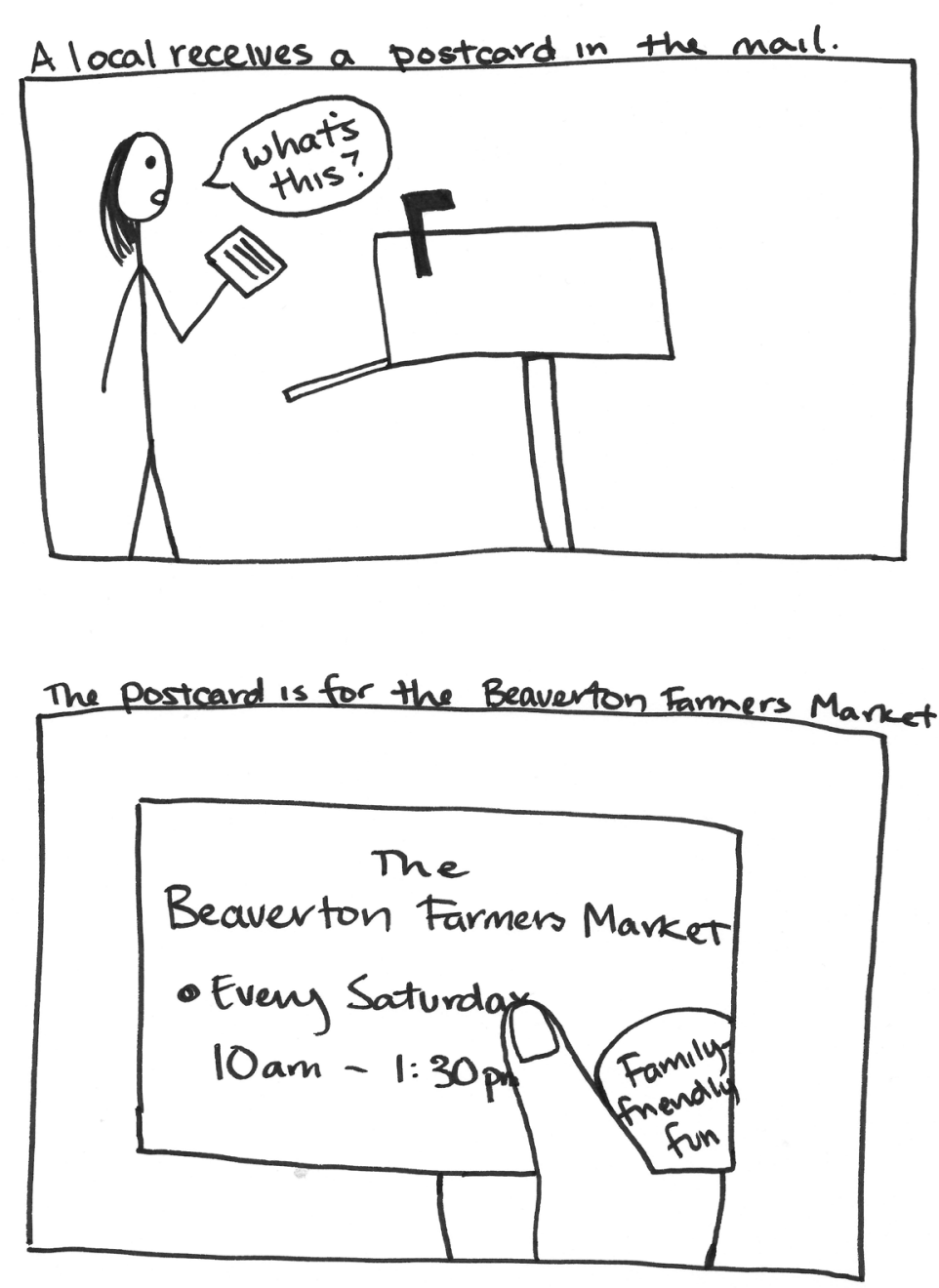
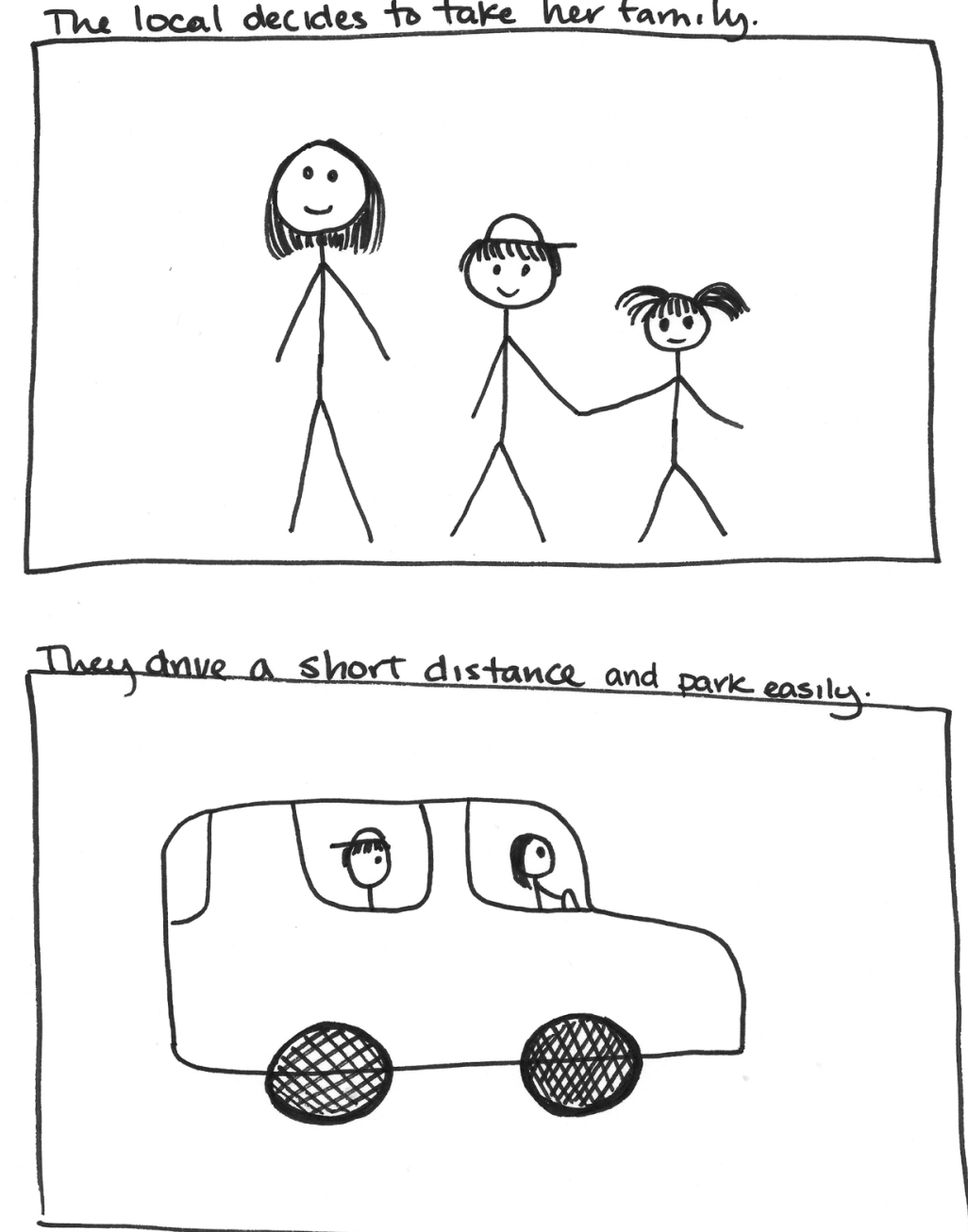

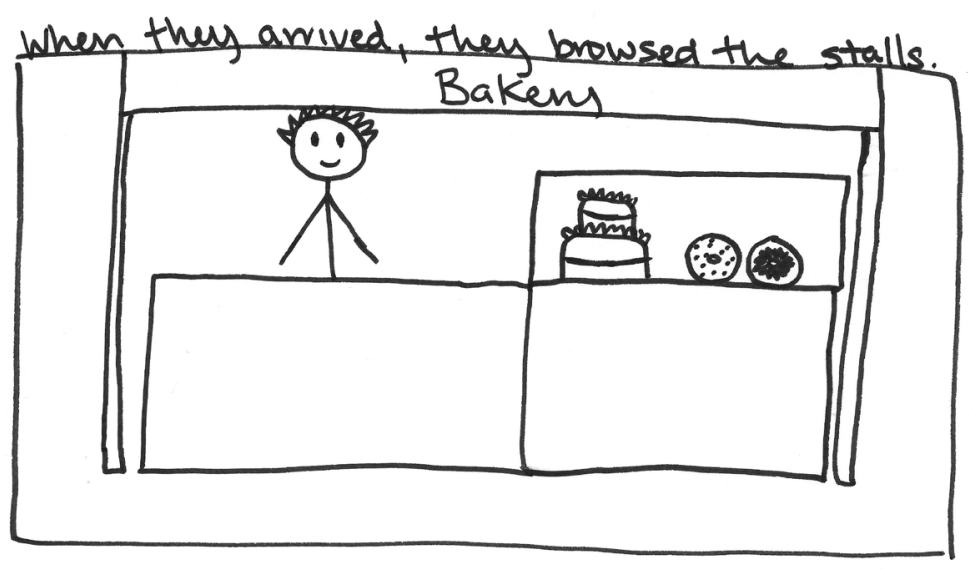
After having fun at the manket, they went
to the librang. This will make a nice weekly outing.

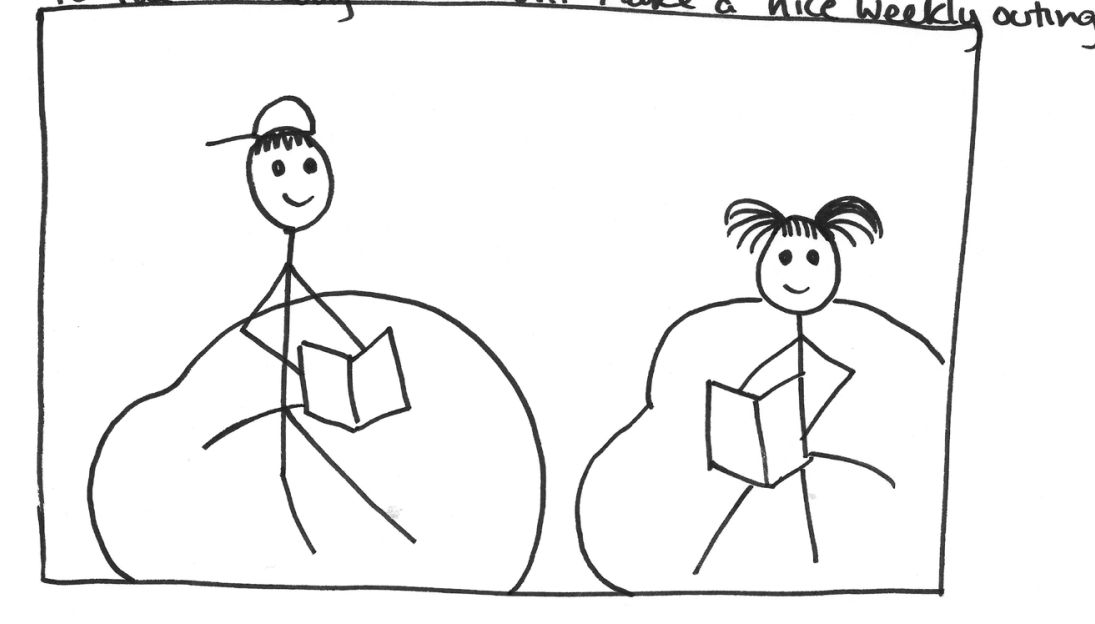



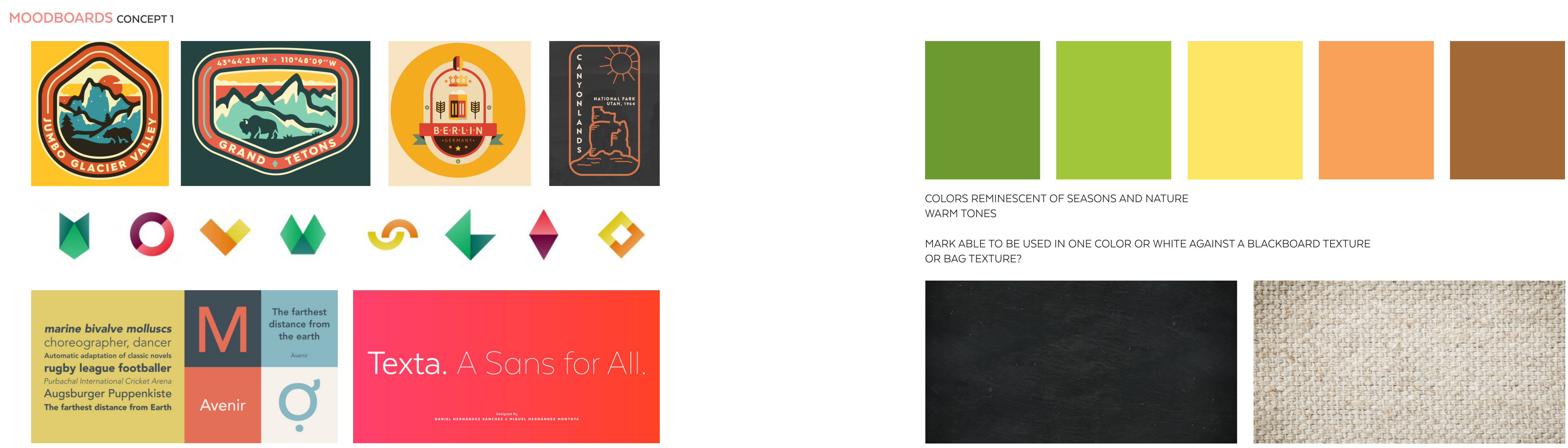

COLORS REMINESCENT OF SEASONS AND NATURE

WARM TONES

MARK ABLE TO BE USED IN ONE COLOR OR WHITE AGAINST A BLACKBOARD TEXTURE OR BAG TEXTURE?
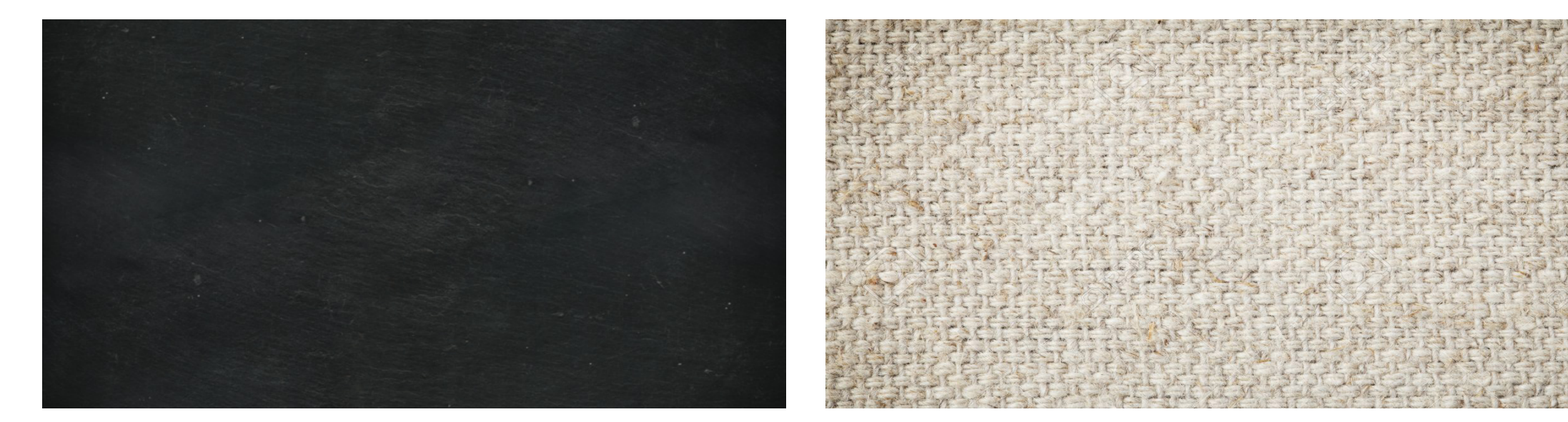
Blue Valley

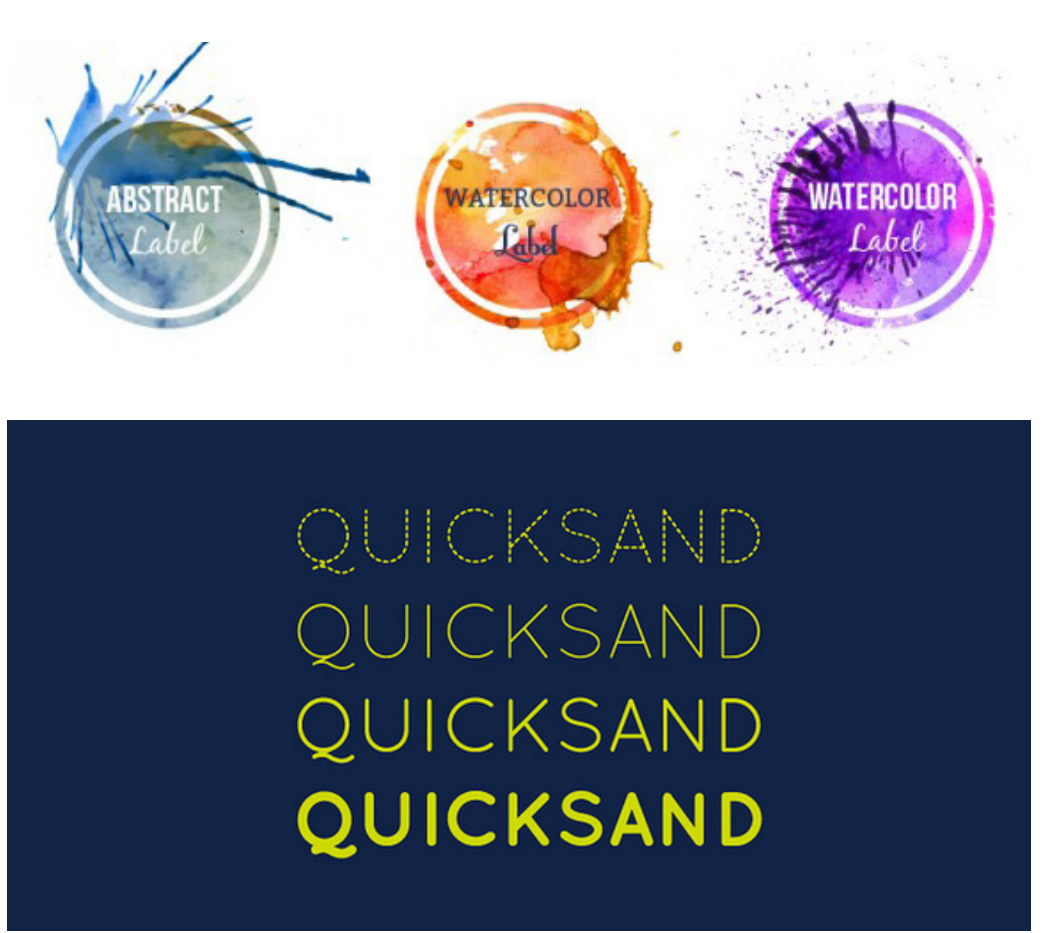

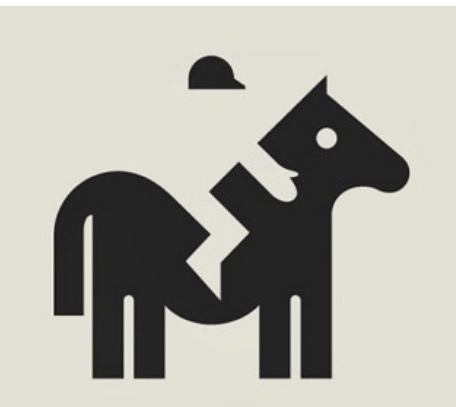

Conem psum

Chau Philomene One

Regular Italic

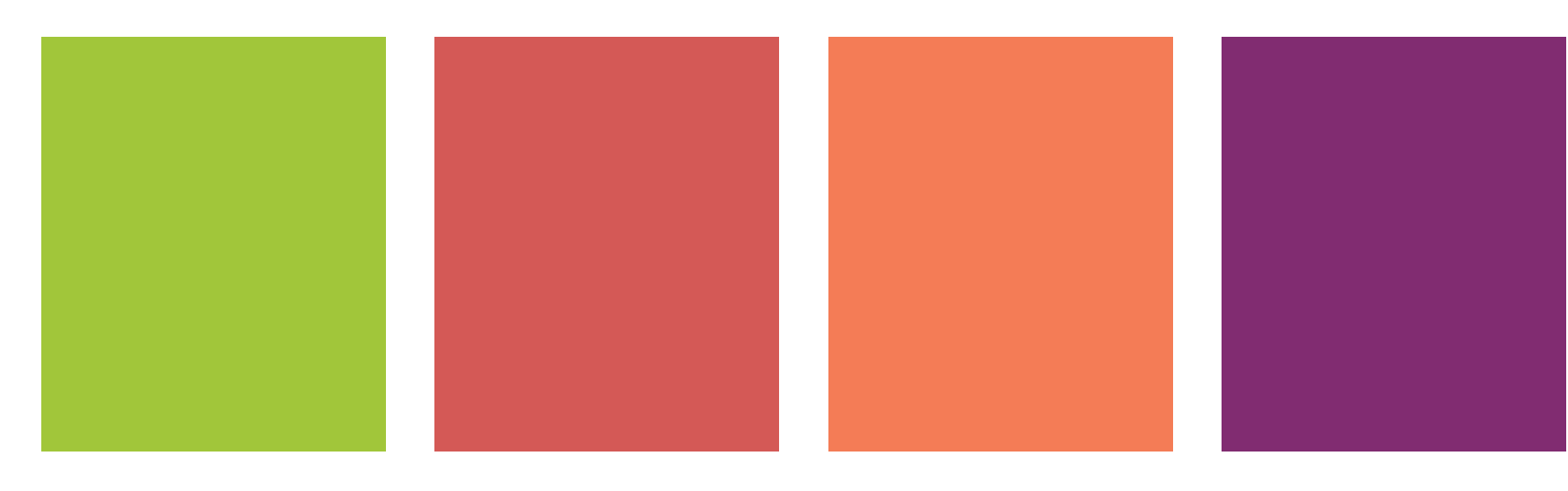

COLORS REMINESCENT OF PRODUCE AT THE MARKET

WATERCOLOR TEXTURE OF MARK / OVERLAPPING OPACITY / NEGATIVE SPACE

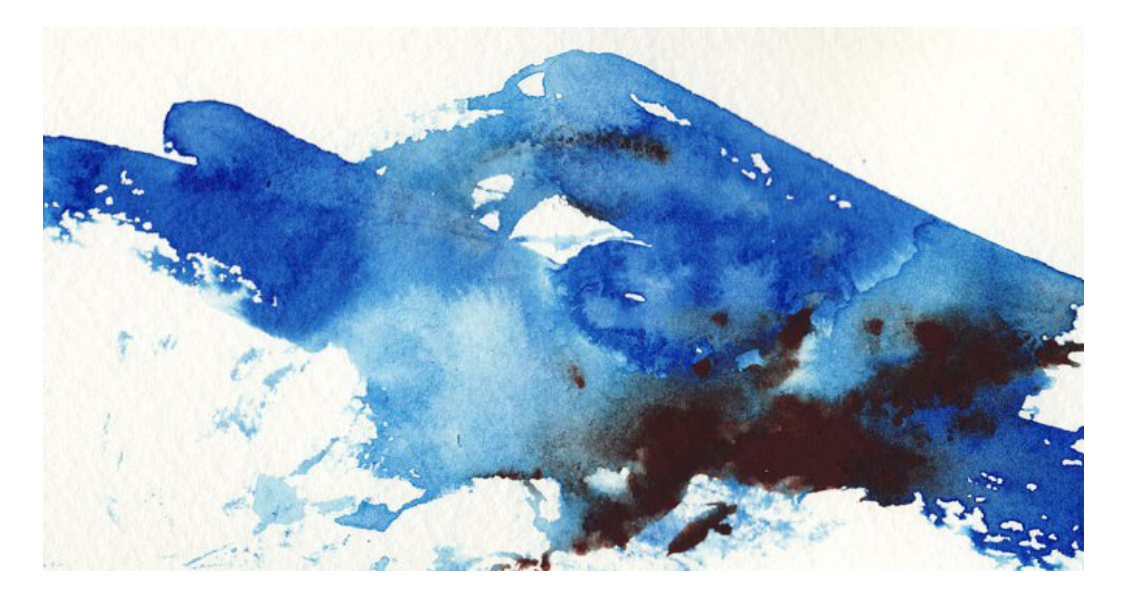



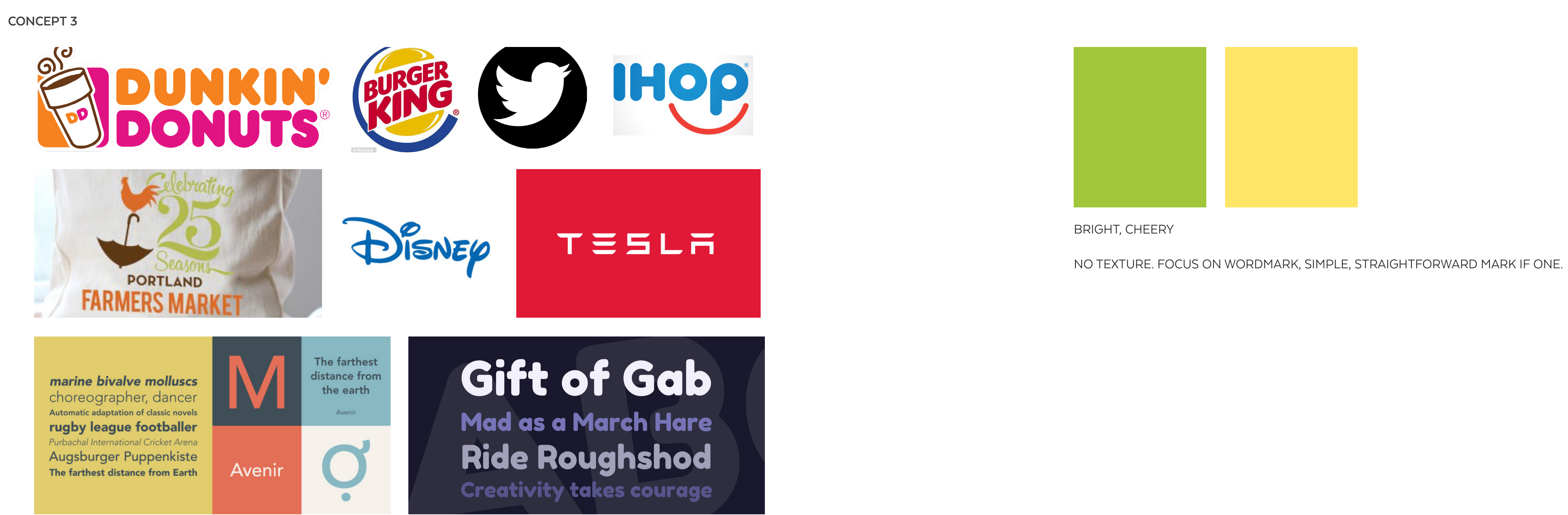
SKETCHES

For the most part, these wordmark and logomark sketches took direct mspiration of the moodboard assigned to each one. At the same time, ay were therined, quick ideas. The first concept played more on the (y) as well as expermentation with connecting the community with the market. The second concept took a more literal and was the most experimental in that it played more with type instead of a logomark, as well as simple, straightforward imagery.
CONCEPT 1

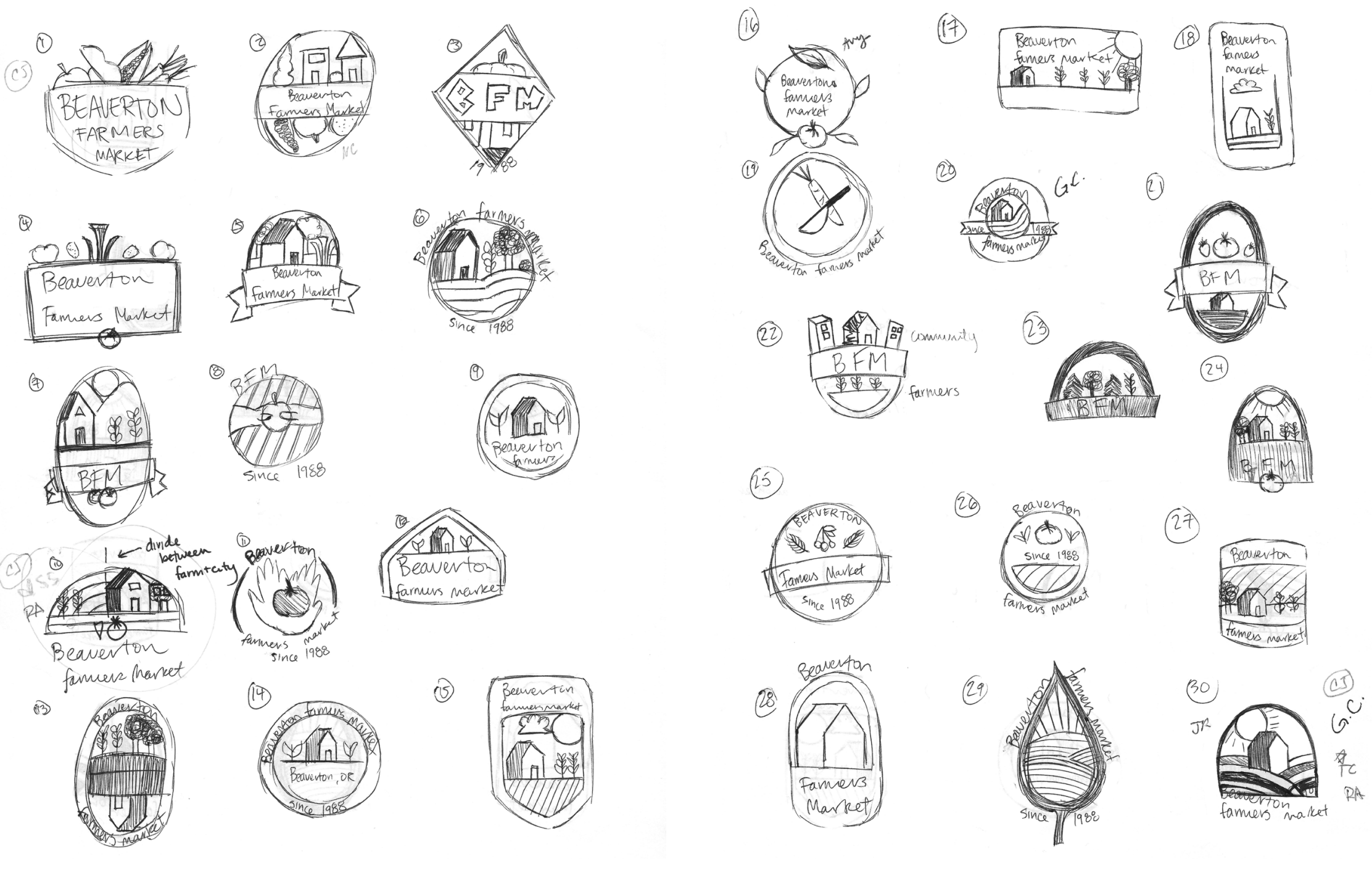



(3) (3)

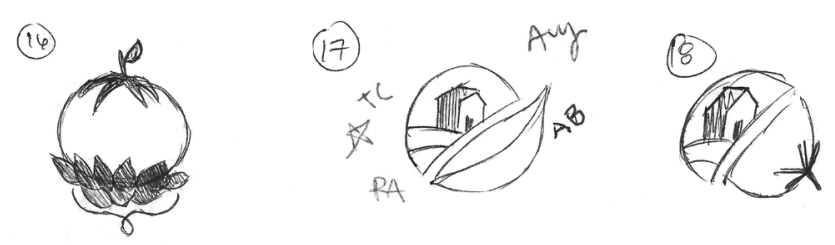
(1)

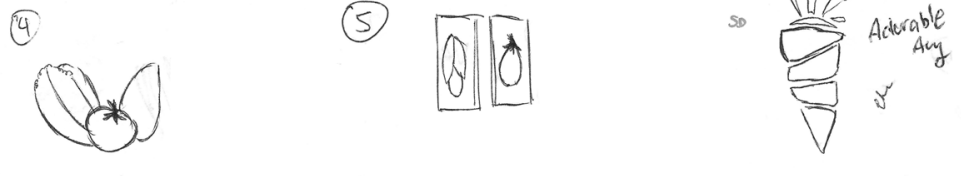
(2) (3)
* (1) * (10) (a) (a)
(13) (1)
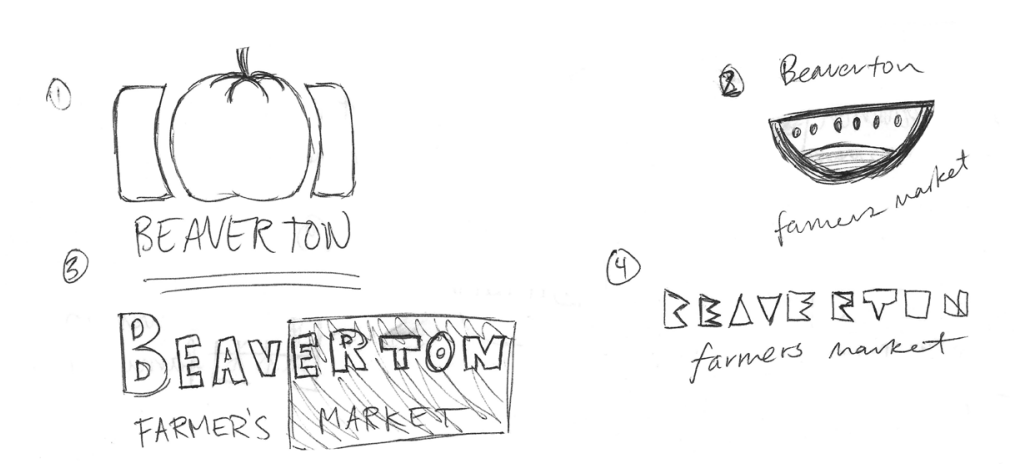

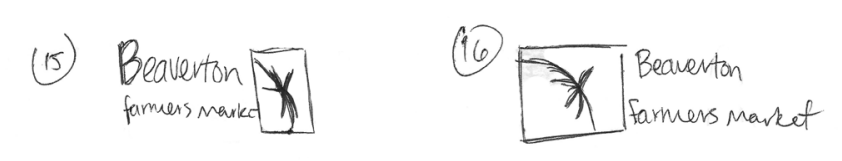
(1) B A

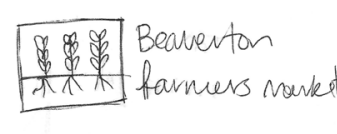

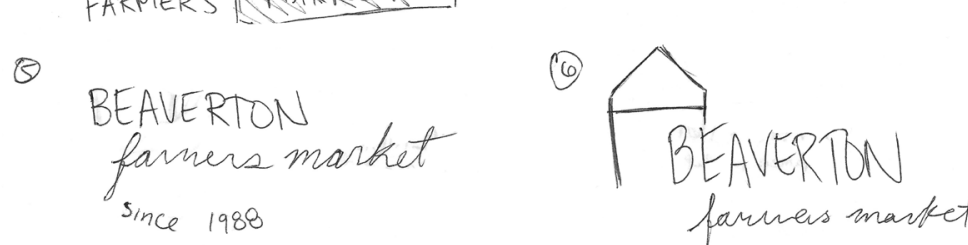

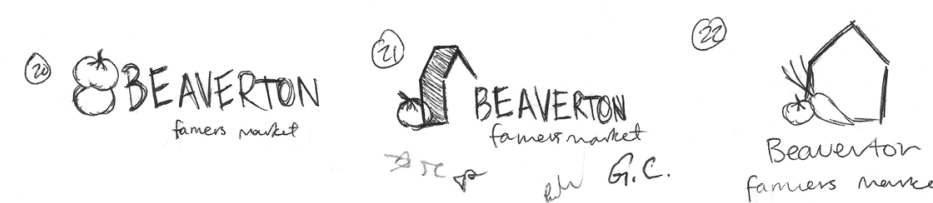
(i)
(ㄱ)

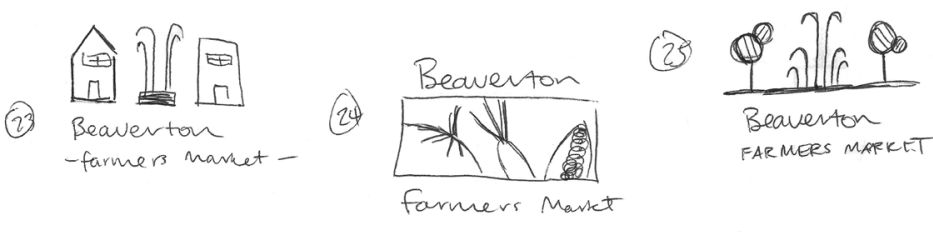

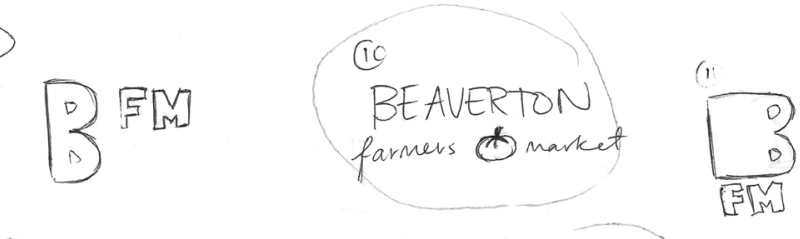

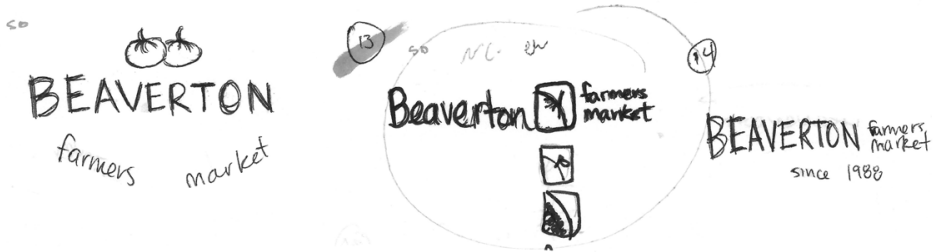

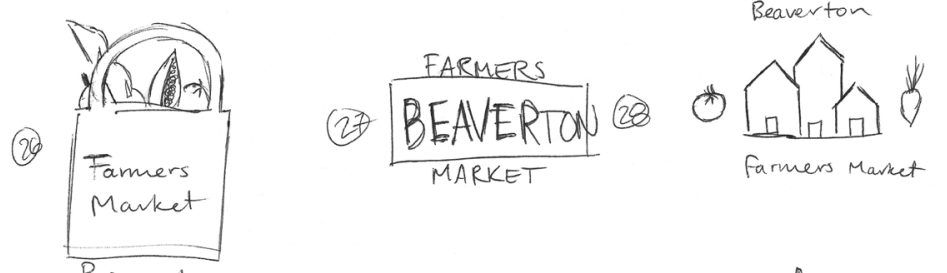

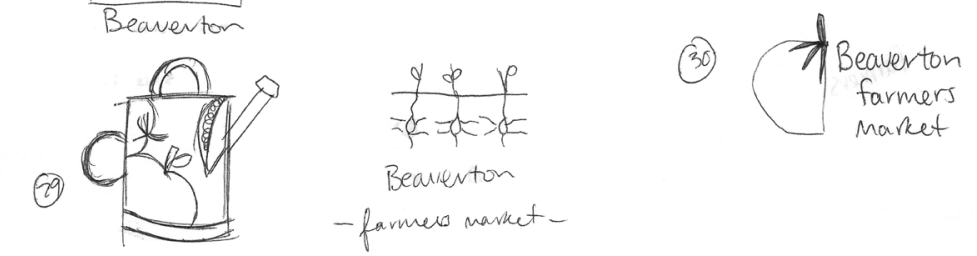


CREATION

STEPS

An important process to creating a brand is developing a style. This can include colors, additional imagery, photography, and so forth. Additionally, some brands benefit from having a tagline, although it is entirely optional. As for the mark itself, refining the logo ultimately took place in three major steps. Naturally, there were quite a few variations in between these phases, but I chose only one or two directions to go

STEPS

STYLE

TAGLINE

REFINING THE MARK 

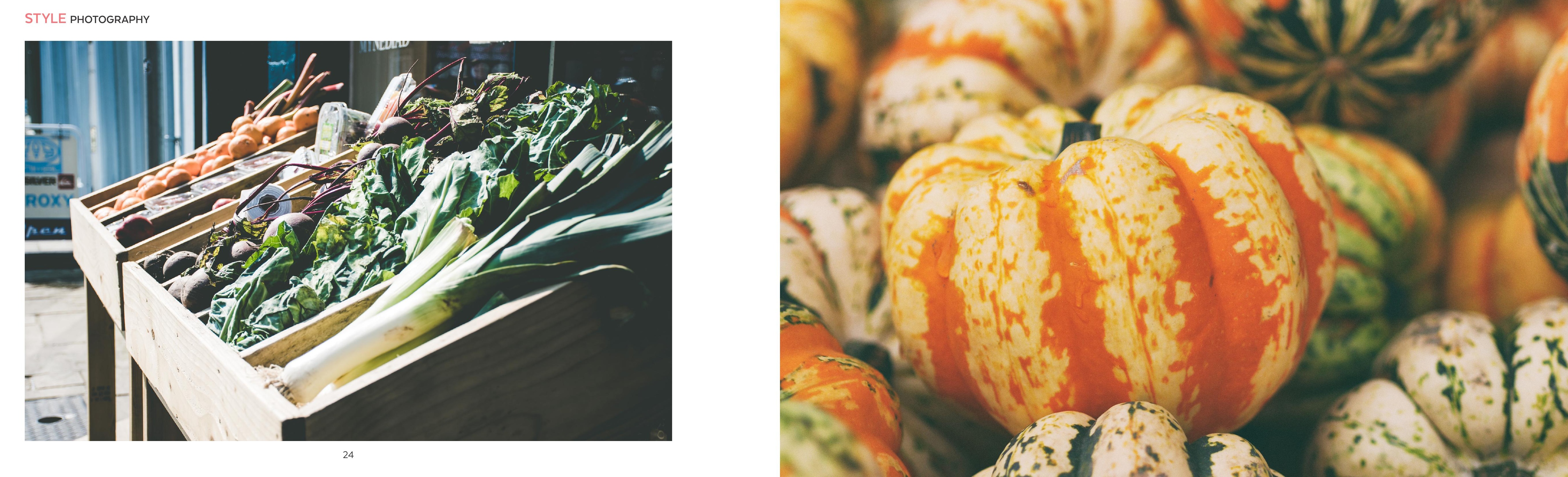

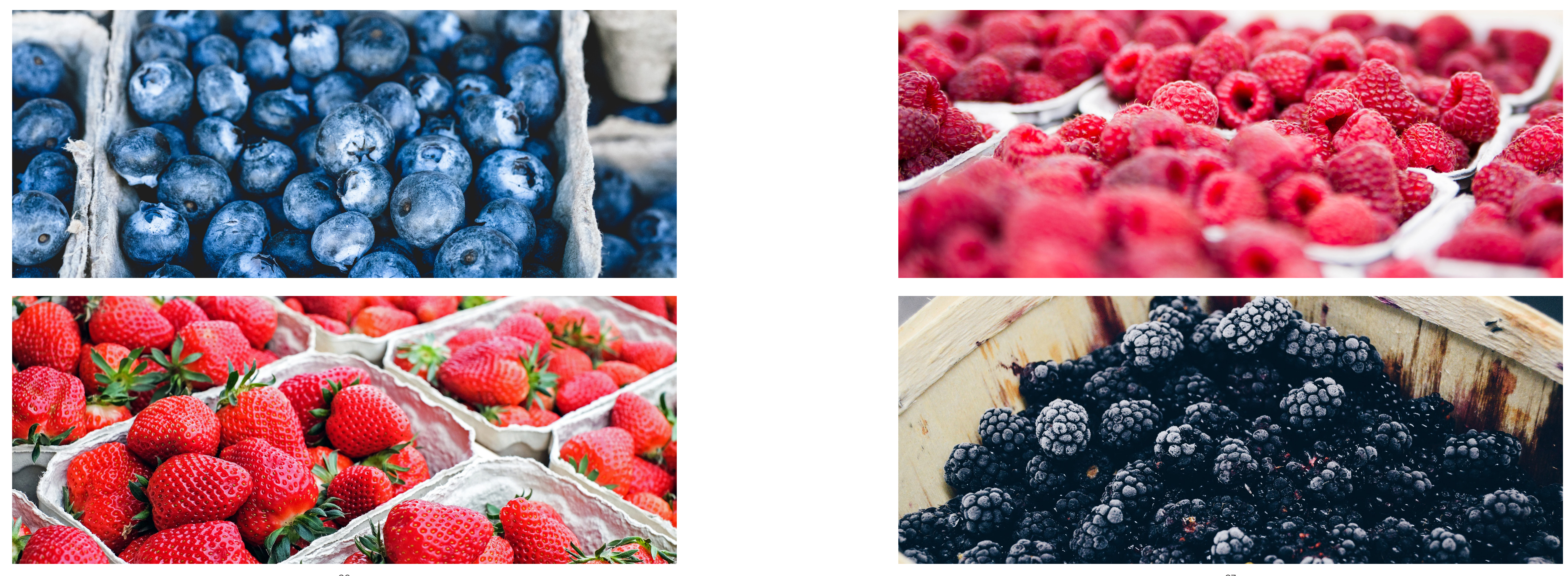
STYLE COLOR

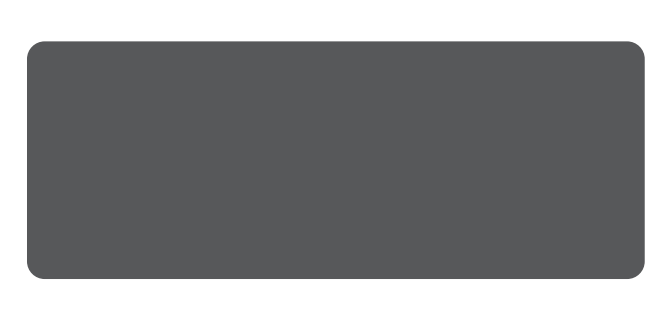

00080

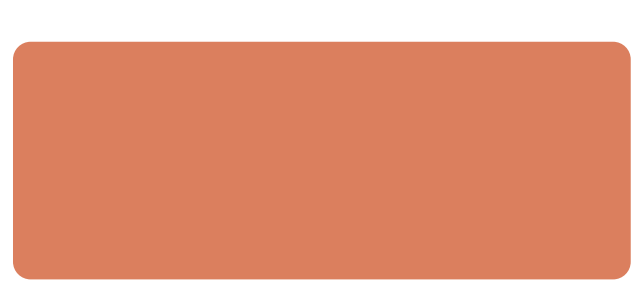

1159660

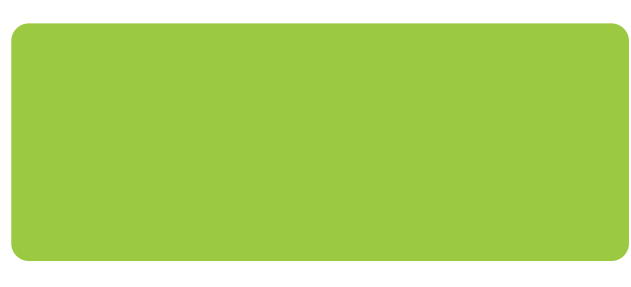

441960

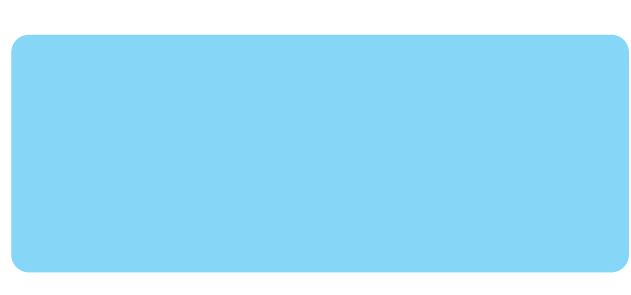

42000
TAGLINE

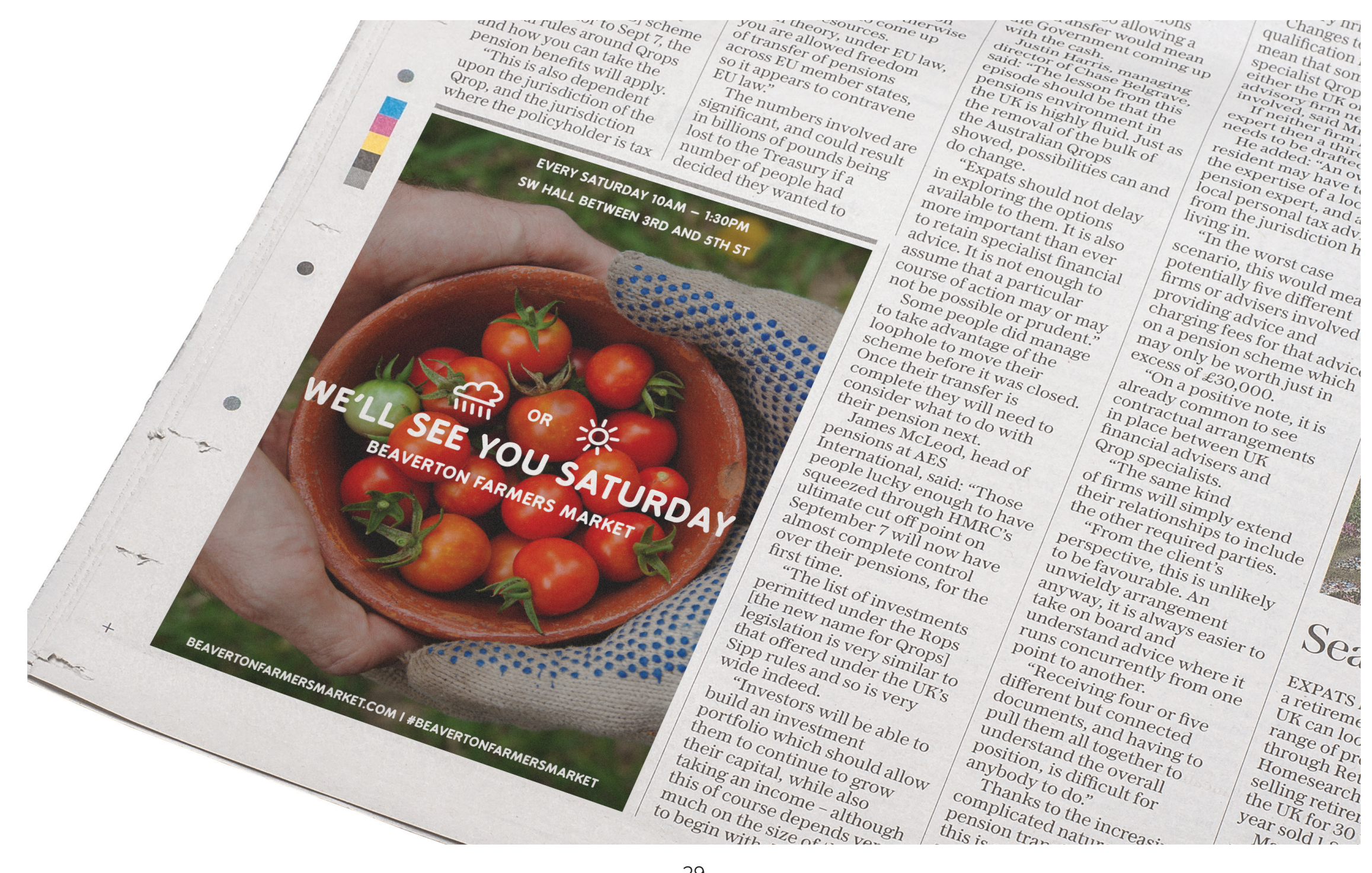




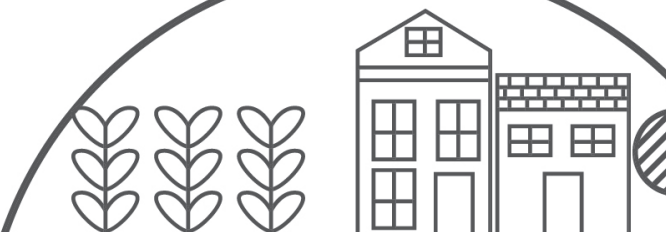

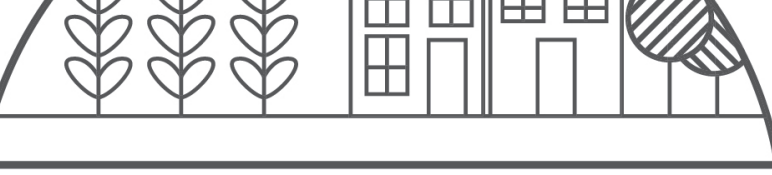

Beaverton Farmers Market

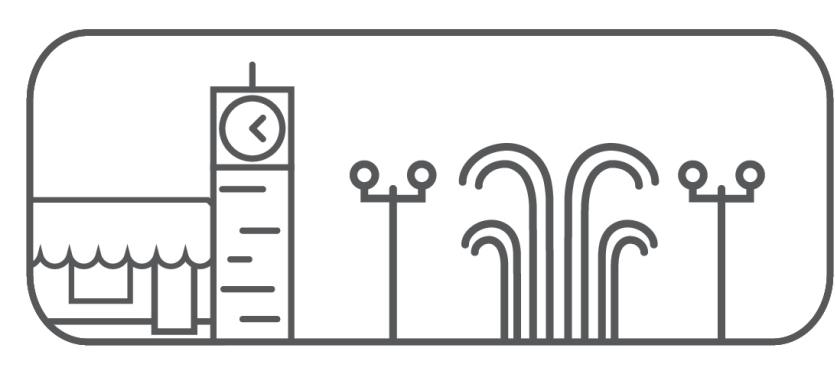

BEAVERTON

- FARMERS MARKET -

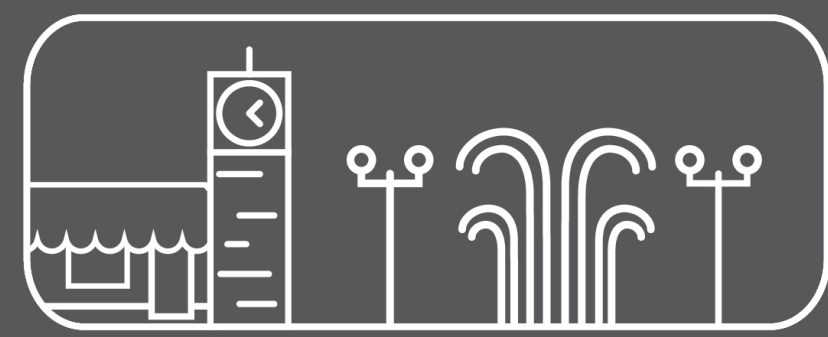

BEAVERTON

- FARMERS MARKET - 


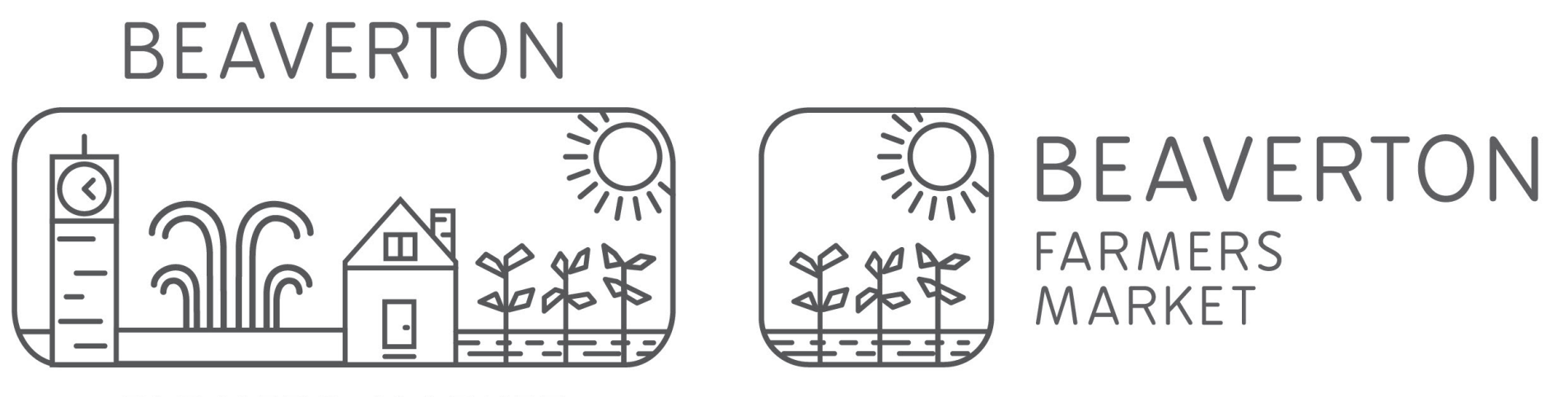
FARMERS MARKET

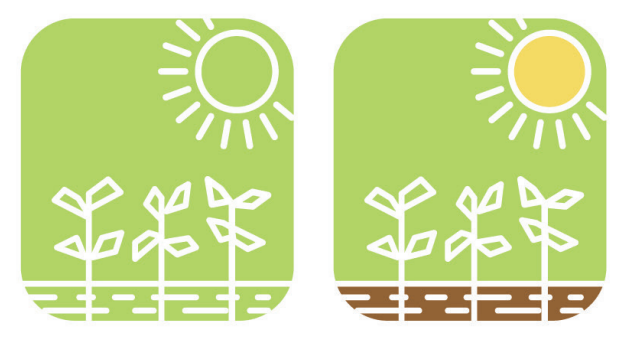

出造年

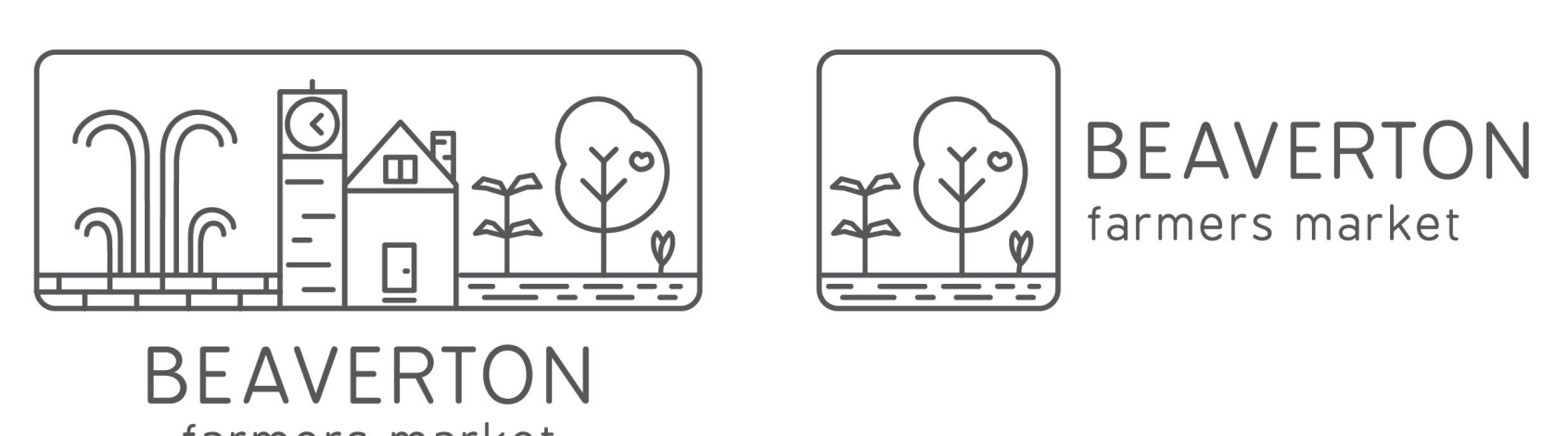

farmers market

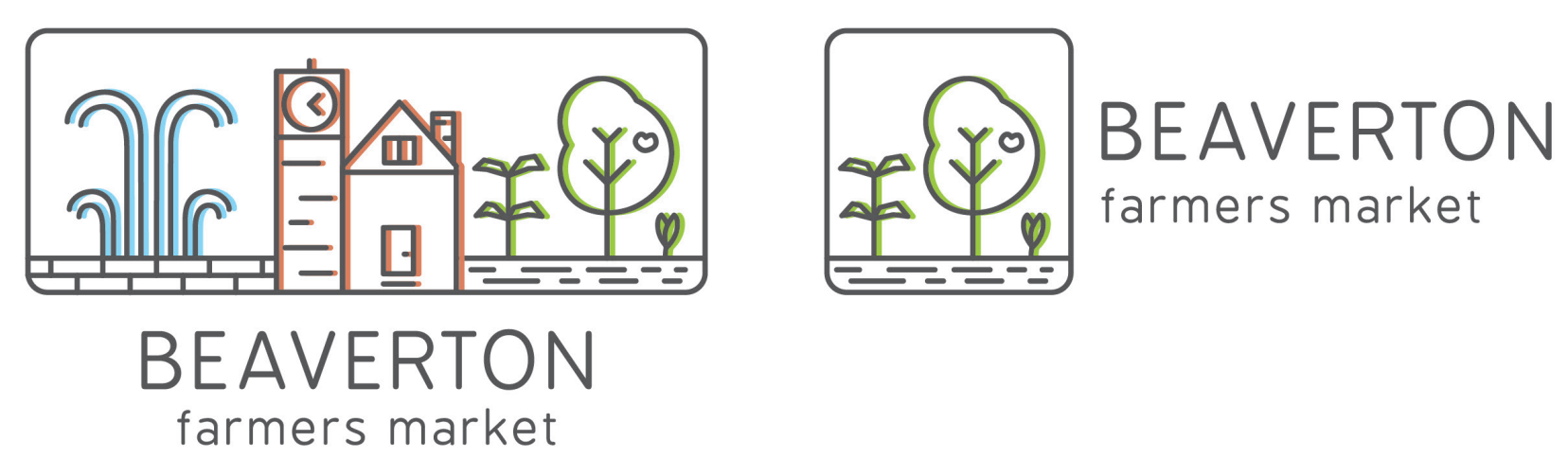




\section{5 CONCLUSION}

\section{MOVING FORWARD}

As previously stated, I do not feel like the project or brand is where I want it to be. However, these are some of my ideas if were to take the project further. I would continue to simplify the mark, while keeping it interesting and still highlighting the unique elements of Beaverton. The colored outlines in the second version of the mark don't look good, as its too minimal and vibrates against the gray lines, so I would either color the entire mark, or leave it a single-color outline. Lastly, I would alter some of the deliverables, as they are not entirely representative of the brand and do not display the mark in a way I like, primarily the advertising essentials (newspaper, postcards, and social media). I would spend more time focusing on integrating the mark and the photographs MOVING FORWARD FINAL THOUGHTS 
FINAL THOUGHTS

In conclusion, I think this process book of developing the Beaverton Farmers Market identity is representatve of he branding pro of the most "invisible" steps of process work is all the research that goes into the existing brand, its goals, and its competitors, as it is hardy shown to anyone other than clients or fellow designers. Not to mention, when creating a new brand from scratch, there is also additional work with first identifying a target audience, a name for the brand, and more Certain elements of the process may still change from designer to designer, how one goes about coming up with keywords and ideas for brand, how many sketches one does, how long one spends developing alternative marks before going with one idea, and so on. Many of these same steps are taken by designers in one form or another.

In the end, however, a well-thought-out brand identity still requires a lo of time and exploration. With smaller companies or personal branding projects, for example, there may not be as much of a need for thoroughly researching competitors, developing a tagline, or developing deliverables beyond a business card and a basic stationery set, but it is still importa to develop a mark and a system that are representative of the brand. Developing a new brand identity should be done on a case-by-case basis and reflect the newly established needs for the brand.
A bulk of the work of developing a brand also comes from the actual creation of the logo and wordmark itself. The very first sketch may turn out to be the final mark with only a little adjustment, but it most always doesn't work out that way, and it should certainly not be treated as such The sketches themselves may take up to ten hours, give or take, and tha doesn't include the revisions to the mark. I spent several hours alone jus looking at typefaces for the wordmak, not to mention creating ninety sketches that weren't too identical.

Once the mark is solidified, developing a color scheme and other

esthetics may also be a long process. Even though I knew I wanted

use photographs and had a style in mind, it still took a while to narro

down how I wanted the photographs and mark to interact. Until the at-

the-time final version of this project, I did not even know that I preferred a lack of color, with a focus on a white mark against a photograph, or the mark set in a single color.

will reiterate once more that I do not consider the project complete, bat at the time, I have no intention of going back and filishing it to the standard I want. Regardless of whether I could get a final portfolio-worthy project out of it, I still learned a lot about the branding process. Until this project, I had only erroneously assumed that there were just unspoken rules about how to go about creating a brand identity. I was exposed to scholarly research, as well as books written by creative directors in the field. I could speak to peers in my field daily about the best way to approach the redesign, as well as what options they were exploring to supplement their research.

I will take what I have learned and apply it to future projects. I will use this knowledge to better myself as a designer and make my work mor efficient. But as it stands now, and for the near future, the Beaverton Farmers Market redesign will remain a work in progress. 

